DOI 10.26886/2523-6946.1(1)2017.2

UDC 612.82:57.034:616.839-008.6

\title{
ELECTROENCEFALOGRAPHICAL SYMPTOMS OF THE PSYCHOVEGETATIVE DERMA-COSMETOLOGICAL GENESIS
}

\author{
V. Ye. Hladchuk, PhD, MD, DSc
}

Hladchuk Medical Aesthetic Center, Ukraine, Kiev

The main point of exploration is an establishment of cosmetological defective influence and skin itch on psychovegetative syndrome among chronic eczema patients. Following this aim the electroencefalogram method was principal. 40 chronic eczema patients were examined. According to the psychological investigation and the main exploration the psychovegetative syndrome showed up leading some define bioelectric brain activity changes that can prove an advantage of limbico-reticular disfunction complex (according to EEG). Observational datas are persistent enough to allow the newest development of brain restorative and dilatory module systems.

Keywords: eczema, psychological investigation, electroencefalogram.

B. E. Гладчук, доктор медицинских наук. Электроэнцефралографрические признаки психовегетативного синдрома дерматокосметологического генеза / Hladchuk Medical Aesthetic Center, Украина, Киев

Предметом исследования является установление значения влияния косметологического дефекта и зуда кожи на развитие психовегетативного синдрома у больных экземой. С этой целью методом психологического исследования и с помощью электроэнцефралограммы было обследовано 40 больных хронической истинной экземой. Выявлено наличие психовегетативного синдрома у всех пациентов (по данных психологического тестирования), а так 
же достоверные изменения биоэлектрической активности головного мозга, свидетельствующие о преимущественной дисфрункции лимбико-ретикулярного комплекса (по данным ЭЭГ). Достоверность полученных данных позволяет рекомендовать разработку новых методов лечения больных экземой $c$ возможностью модуляции равновесия деятельности активирующих и тормозящих регулирующих систем мозга.

Ключевые слова: экзема, психовегетативный синдром, электроэнцефралограмма.

Introduction. Different medical specialists are found of solving the developing psychovegetative problem in eczema patients. There are two highlighted methods of diagnostic - EEG and REG (mostly known as electroencefalogram and radioencefalogram). The medical literature misconcepts the role of limbic-reticular structural complexes in the changes of brain indicators in functions that are registered by the EEG, the value of the interhemispheric asymmetry with regulative psychovegetative disorders. It is especially true when the structure of diseases changes, the origin of which is due to psychologic disorders and highlights the modern features of the vegetative-vascular dystonia syndrome,which is often found in the neuroses.

The purpose of the study is to estimate the values of changes in bioelectrical activity of the brain (using EEG) as an objective criteria of clinical manifestations psychovegetative syndrome of dermatological origin.

Materials and methods. The study included 40 male patients with clinically detected signs of eczematous process and psychovegetative syndrome. The bioelectric brain activity studies was performed on 10channel EEG machine NIHON KONDEN-7300 (Japan). The placing of electrodes on the head surface was carried out in the so-called "10-20 
system" (Ten-Twenty System), which is recommended by the international Federation of EEG and clinical electrophysiology. Conducting EEG studies have measured changes in the bioelectric brain activity according to this exact algorithm:

1) the main symptoms that highlight the General properties of the pattern (main EEG components, amplitudes, characteristics of alpha activity, regional differences, beta activity low frequency, Delta-activity, biopotential field reactivity);

2) Clarified the type, group, class, nature, extent of EEG deviations from the norm on the background bioelectric activity, evaluated the reactivity pattern.

The total valuation of psychophysical status is presented by special survery that permits clear analysation of depression that are showed in such ICD-10 columns as F06.3, F32, F33, F34, F43.2.

Obtained results purpose of which is to get trustworthy datas processed personally on PC (LP "Statistica 6.0").

Results and discussion. Each patient was diagnosed with typical eczema markers which include symmetrical localisations of affected areas (face, limbs, trunk), blurred lines and alternation of affected skin surfaces, itch. The middle grade of depression elicited in $95 \%$, other $5 \%$ - hidden forms of it (latent). At the same time such clinical symptoms as somatic sleep disturbance, appetite and potency decreasing, mood fluctuations are often marked as psychovegetaive syndrome. Eczema victims are often suffer from non-synchronization of sleep biorhythms, season intensifications, panic attacks. (attacks of "biopsy" itching). 


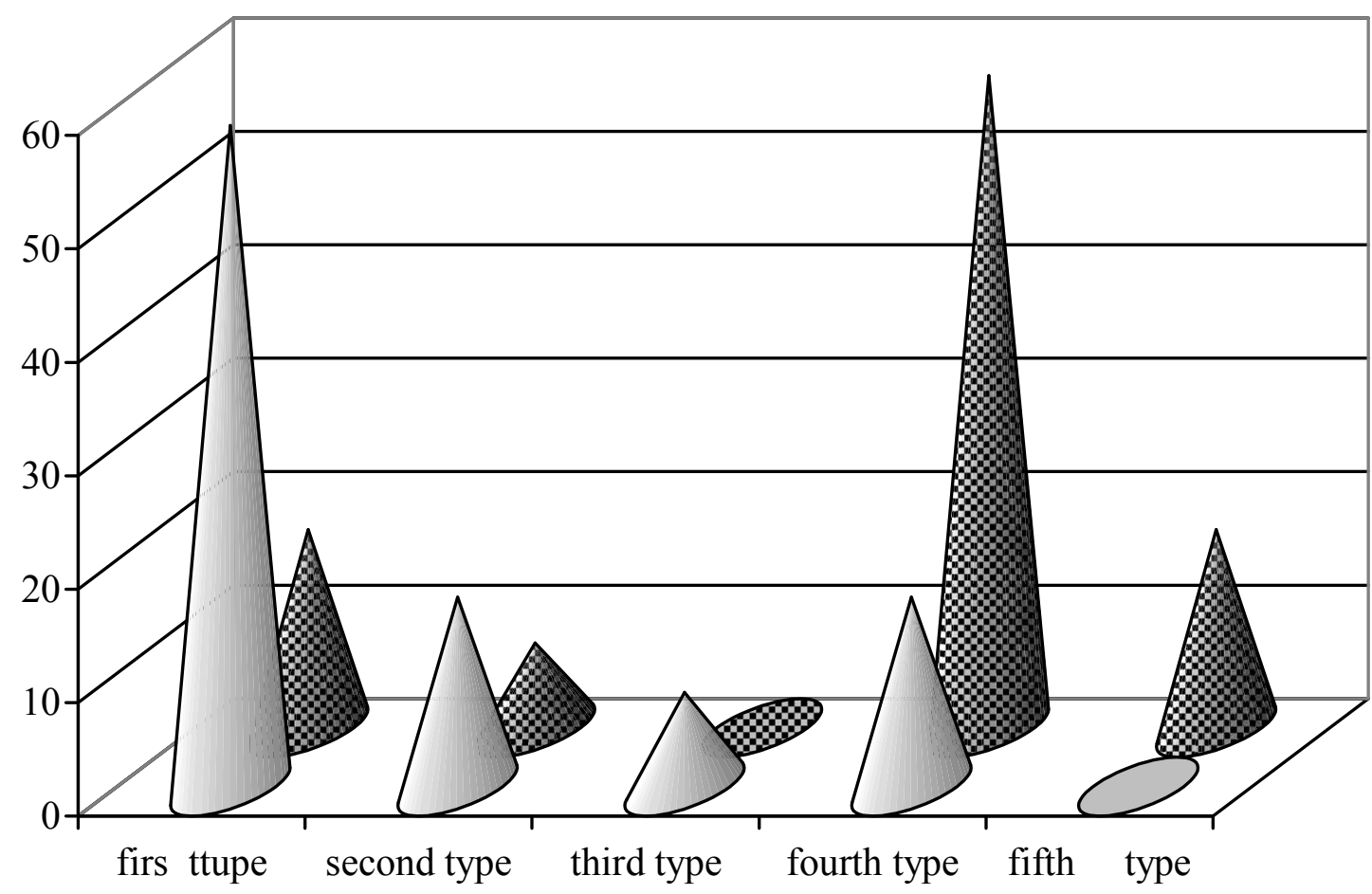

$\square$ healthy affected people $\mathbf{B}$ patients with eczema

Figure. Pattern - EEG in healthy affected people, reliability markers $(p)$ that are mentioned in the text

According to obtained results that are mentioned on the figure, the First EEG type organized "in space and time" marked in $17,5 \%$ of time which is to be exact is $p<0.001$ happens rarely than in healthy people $(58,3 \%)$. The second hypersynchronous or monorhythmical type was diagnosed less often than in healthy people as well $-7,5 \%(p<0.01)$ versus $16,7 \%$. The third desynchronous type was not found at all. The fourth disorganized with main a-activity registered exactly more often than in patients $p<0.001$ or $57,5 \%$ to $16,7 \%$. The fifth type is disorganised wit maining theta- and delta-activity was noticed in $17,5 \%$ of patients but it was not diagnosed in healthy people. Patients with "biopsy itch" $(17,5 \%)$ were concluded with typical "epileptiform" pattern on EEG.

Obtained results give us evidence of fact that in cases of developing depression in eczema victims delta- theta- activities are increasing and alpha- and betta- activities are lowering. Also the regional lowering 
differences between superior and inferior part of the brain and increasing activity of the right hemisphere inverse the left were remarked. Under emotional influences which firstly include cosmetic defect on the skin surface functional system is forming enclosing lowering of the brain educations which provides the the best implementation of this sensory activity - under the pressure of negative emotions internal and interhemispheric cross correlation coefficients are falling.

In fact this motivationally-emotional and vegetative reactions of the integral human are united in one functional block and so this is not an accident that limbic system is marked as "emotional" and "visceral" brain. If healthy person is energetically provided by appropriate vegetative accompaniment in pathological cases the psychovegetative condition takes place inside of which emotional and inadequate (the lowest or the highest) are retaining. The stage of the limbic disorganisation reflects the adaptative level which is provided by limbic-reticular complex. This disorders display some dominative fenomens like anxiety, depression, hypohondria, astheny, hysteria [1-5]. Two types of brain homeostasis modifications (activating or synchronizing) where are some violations of descending and ascending reticular formation systems take place are factors of the vegetative dysfunctions pathogenesis of nonspecific brain systems [6-8]. All mentioned examples define some sorts of disorientation like intrasystemic, intersystemic, interhemispheric disbalances. And at the same time the violation mechanism of integrative brain activity projects as vegetative vessels conducting at the frustration segment and it is more difficult in comparison with mechanisms of irritation and destruction which are main characteristic for segmentary vegetative vessels frustration.

As the leading factors which cause psychovegetative mental syndrome, the role of acute and chronic emotional stress is obvious. Emotional frustration is the main factor which defines violations of normal 
nonspecific systems functioning of a brain and causing changes of integrative activity (the disintegration syndrome).

Conclusion. Patients with true chronic eczema who have an appearance of rash and skin surface itch are often have psychovegetative syndrome with bioelectric activity changes as well (according to EEG). Disturbances in the regulatory brain systems (first of all - a limbic-reticular complex) considerably is influenced by factors of a skin damage (existence of cosmetic defect and an intensive itch). The perspective of further studies is an exploration of generative activation and inhibition mechanisms in certain regulative centers in the brain systems and developing of new effective methods of complex therapy that will allow modulation of influence balance in activation and inhibition systems in eczema patients.

\section{Literature:}

1. Коваленко І. В. Психосоматичні розлади: діагностика та лікування / І. В. Коваленко. - Вінниця : Консоль, 2005. - 32 с.

2. Thome I. Acute psychosis after injection of regulated interferon alpha-2A II. Thome, U. Knopf // Eur. Psychiatr. - 2003. - Vol. 18(3). - P. 142-143.

3. Treatment for the initial acute phase of first-episode psychosis in a realworld setting / D. Wade, S. Harrigan, M. Harris et al. // Psychiatr. Bull. 2006. - Vol. 30(4). - P. 120-131.

4. Van Praag H.V. Can stress cause depression? / H.V. Van Praag // World J. Biol. Psychiatr. 2005. - Vol. 6, Suppl. 2. - P. 5-22.

5. Wallace J. Ethics and psychiatric genetics: is it ethical to test for "Depression genes"? / J. Wallace // Psychiatr. Bull. - 2004. - Vol. 28(8). P. 279-280.

6. Fink M. Is the practice of ECT ethical? / M. Fink // World J. Biol. Psychiatr. - 2005. - Vol. 6, Suppl. 2. - P. 38-43. 
7. Holwes J. Fitting the biopsychosocial jigsaw together / J. Holwes // Br. J. of Psychiatr. - 2000. - N. 177. - P. 93-94.

8. The care provided by general practitioners for persistent depression / T.W.D.P. Van Os, R.V.S. Van Den Brink, K. Van Der Meer, J. Ormel // Eur. Psychiatr. - 2006. - Vol. 21(2). - P. 87-92.

\section{References:}

1. Kovalenko I.V. (2005). Psyhosomatychni rozlady: diagnostyka ta likuvannja [Psychosomatic Disorders: Diagnosis and Treatment]. Vinnitsa: Konsol'. [in Ukrainian].

2. Thome I., Knopf U. (2003). Acute psychosis after injection of regulated interferon alpha-2A. Eur. Psychiatr., 18(3) 142-143. [in English].

3. Wade D., Harrigan S., Harris M. et al. (2006). Treatment for the initial acute phase of first-episode psychosis in a real-world setting. Psychiatr. Bull., 30(4), 120-131. [in English].

4. Van Praag H. V. (2005). Can stress cause depression? World J. Biol. Psychiatr., 6(Suppl. 2), 5-22. [in English].

5. Wallace J. (2004). Ethics and psychiatric genetics: is it ethical to test for “Depression genes"? Psychiatr. Bull., 28(8), 279-280. [in English].

6. Fink M. (2005). Is the practice of ECT ethical? World J. Biol. Psychiatr., 6(Suppl.2), 38-43. [in English].

7. Holwes J. (2000). Fitting the biopsychosocial jigsaw together. Br. J. of Psychiatr., 177, 93-94. [in English].

8. Van Os T.W.D.P., Van Den Brink R.V.S., Van Der Meer K., Ormel J. (2006). The care provided by general practitioners for persistent depression. Eur. Psychiatr., 21(2), 87-92. [in English].

Dermatovenerology and Cosmetology. - 2017. - 1(1). - p. $17-24$ 